\title{
Zooplankton vertical migration in two Sahara lakes with contrasting biotic environments
}

\author{
Henri J. Dumont
}

Department of Biology, Limnology section, Ghent University, Belgium and Department of Ecology, Jinan University, Guangzhou, China.

* Corresponding author: henri.dumont@ugent.be

Received: 19/02/18 Accepted: 17/07/18

\begin{abstract}
Zooplankton vertical migration in two Sahara lakes with contrasting biotic environments

In two Saharan freshwater lakes (gueltas), 3-6 m deep, one with and one without fish, zooplankton migrated vertically. The guelta with fish had a very impoverished zooplankton, mainly composed of copepodids of cyclopoid copepods. They showed a strong diurnal migration. The guelta without fish had Daphnia, Asplanchna, and the fairy shrimp Streptocephalus. Daphnia migrated normally at first, but was later disturbed by Streptocephalus that moved around in swarms and physically interfered with the smaller zooplankton. Interference competition is a factor to be considered whenever several species of zooplankton migrate side by side. This may result in a vertical stratification of species, and in extreme cases, in reverse migration.
\end{abstract}

Key words: zooplankton, diurnal migration, predation, competition, Streptocephalus, Asplanchna, cyclopoids, Sahara

\section{RESUMEN}

\section{Migración vertical del zooplankton en dos lagos del Sahara con entornos bióticos contrastantes}

En dos lagos saharianos de agua dulce (guelta), de 3-6 m de profundidad, uno con y otro sin peces, se observó la migración vertical del zooplancton. La guelta con peces tenía un zooplancton muy empobrecido, compuesto principalmente de copépodos ciclopoideos. Mostraron una fuerte migración diurna. La guelta sin peces tuvo Daphnia, Asplanchna y el camarón Streptocephalus. La Daphnia migró normalmente al principio, pero luego fue perturbada por el Streptocephalus que se movió alrededor de la guelta en grupos e interfirió físicamente con el zooplancton más pequeño. La competencia por interferencia es un factor por considerar cada vez que varias especies de zooplancton migran una al lado de la otra. Esto puede dar como resultado una estratificación vertical de las especies y, en casos extremos, una migración inversa.

Palabras clave: zooplancton, migración diaria, predación, competición, Streptocephalus, Asplanchna, ciclópidos, Sáhara 


\section{INTRODUCTION}

Diel vertical migration of the various size groups of the marine and freshwater zooplankton is possibly the most common and widespread animal migration on earth (Williamson et al., 2011). That zooplankters swim to the surface during the night hours, and migrate down during the day has been known since the 19th century, and has generated hundreds of papers. One early review, still mechanistic in its approach, was by Cushing (1951). It was followed by many updates, such as Hutchinson (1967), Lampert (1989), Dumont \& De Meester (1990), Ringelberg (2010) and others, in which the tone became more and more Darwinian. It has become customary to call factors that are under selection ultimate, whereas signals that initiate movements are called proximate. Some factors are both. Light, for example, is as well a signal for migration to begin (Ringelberg, 1999), as a fitness component, via damage done to tissues and DNA, especially by short wavelengths (Hairston, 1979). But light also influences predation pressure, especially by fish, on animals that fail to swim down to deep dark layers rapidly enough during daytime, may be a strong selection power (Zaret and Suffern, 1976; Gliwicz, 1986a; Lampert, 1989). Swimming to the surface too early may also be under selection, as even the light provided by the rise of the full moon has been found adequate to allow fish to locate and forage on crustacean zooplankters reaching the surface too early (Gliwicz, 1986b).

The Sahara is a place with abundant light but few freshwater lakes. Still, in appropriate, deeply eroded mountain environments, freshwaters of variable duration, with a depth of up to $12 \mathrm{~m}$ (although modally not more than 3-4 m) occur. They are locally called guelta (diminutive: gueltet). Partially related with depth are permanence and salinity, which depend on water renewal rate. Permanent freshwater gueltas usually have a variety of fish, non-permanent ones (even if so

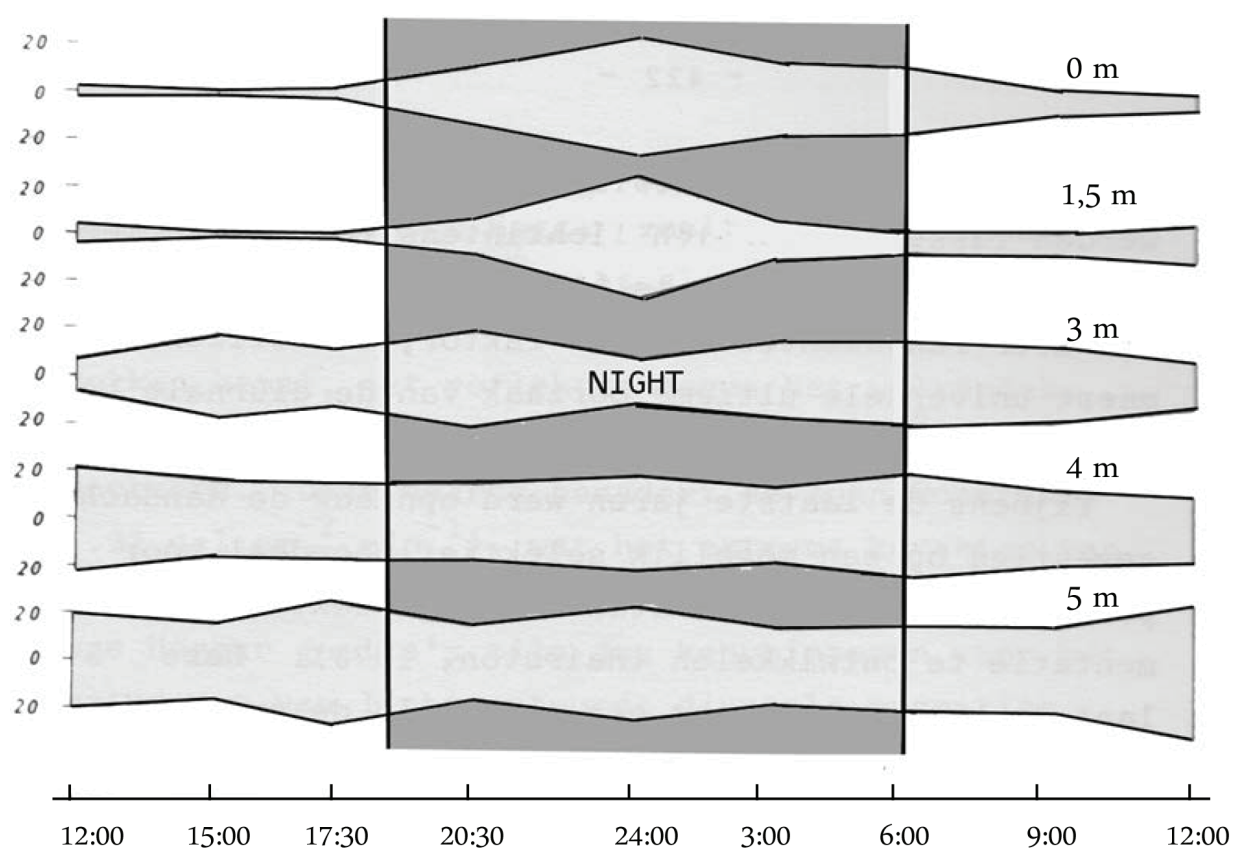

Figure 1. Diurnal migration of cyclopoids in Guelta Molomhar, Adrar, Mauretania. An outspoken upward movement occurred at the surface and down to $1.5 \mathrm{~m}$ during the night. Numbers here became extremely low during the day. Migration became insignificant below 3 m. Migración diurna de ciclopoidos en Guelta Molomhar, Adrar, Mauritania. Un claro movimiento ascendente ocurrió en la superficie y hasta $1.5 \mathrm{~m}$ durante la noche. El número de ciclopoidos fue bastante bajo durante el día. La migración fue insignificante por debajo de los tres metros. 
deep that they fall dry only once per decade on average) are fishless.

Here, I comment on the results of two 24 hour cycles on Molomhar and Gueltet Zli, two gueltas in the Adrar, a mountainous area in western Mauretania, Western Sahara, in winter 1976.

\section{MATERIAL AND METHODS}

Molomhar (280 m a.s.1, 20 $35^{\prime} \mathrm{N}, 13^{\circ} 09^{\prime} \mathrm{W}$; annual precipitation at the nearby city of Atar 70 $\mathrm{mm}$ ). is situated in a deep, narrow canyon with the same name. It has almost vertical walls, such that sampling down to $6 \mathrm{~m}$ could simply be done from a ledge. The guelta is elongated, with a length of about $100 \mathrm{~m}$, and a width of not more than $3-5 \mathrm{~m}$ in most places. The water is rather transparent and has a green algal colour, but no exact measurements were taken. Its permanent nature is underscored by the presence of at least four species of fish, including the pelagic Barbus deserti, up to some $5 \mathrm{~cm}$ in size, and a zooplanktivore. Gueltet Zli (300 m a.s.1, $19^{\circ} 31^{\prime}$ N, $12^{\circ} 47^{\prime}$ W) is situated in a more open landscape, but -typical for most gueltas - lies at the foot of a waterfall that only discharges for few days, after rare torrential rainfall events. It was less than completely full at the time of our visit, but still had depths of over $3 \mathrm{~m}$. The water transparency was higher than in Molomhar, but probably not to the point where it would affect the amplitude of migration (Dodson, 1990). Sampling was

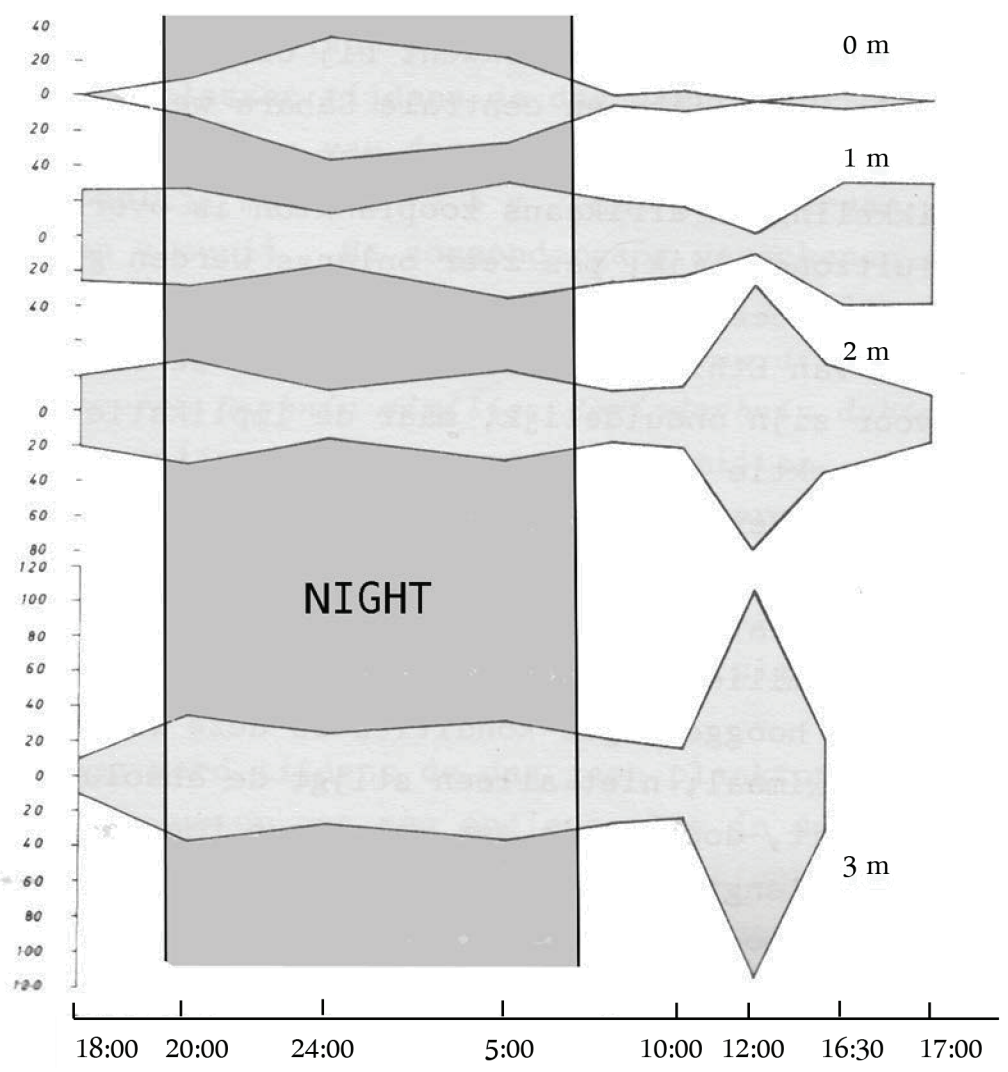

Figure 2. Diurnal migration of Daphnia similis in Gueltet Zli, Adrar, Mauretania. The daytime values at the surface during the day were almost nil but increased during the night. There is no clear evidence of migration in deeper strata, but patchiness occurred, especially at 2 and $3 \mathrm{~m}$ during the second day (last sample at $3 \mathrm{~m}$ was lost). Migración diurna de Daphnia similis en Guelta Molomhar, Adrar, Mauritania. Los valores durante el día en la superficie fueron prácticamente nulos, pero aumentaron durante la noche. No hay evidencia clara de migración a mayor profundidad, pero hubo parches, especialmente durante el segundo día a 2 y 3 metros (la última muestra, a tres metros, se perdió). 
conducted from an inflatable boat, in the center of the lake, which had a diameter of about $50 \mathrm{~m}$. There were no fish, but sizeable numbers of the filter-feeding fairy shrimp Streptocephalus torvicornis (Waga, 1948) could be seen moving around.

Plankton was collected by lowering a 2 liter Friedinger plankton trap to the desired depth, and filtering the contents over a $50 \mu \mathrm{m}$ mesh plankton net. Samples were preserved in $4 \%$ formalin. Samples were counted upon our return to Europe, under a WILD stereomicroscope.

Sampling for vertical migration was carried out for 24 hours on 30-31 January 1976 (Molomhar), and 8-9 February 1976 (Zli), at 3 hour intervals, at the surface, $1.5 \mathrm{~m}, 3 \mathrm{~m}, 4 \mathrm{~m}$, and $5 \mathrm{~m}$ (Molomhar), and at the surface, $1 \mathrm{~m}, 2 \mathrm{~m}$, and $3 \mathrm{~m}$ (Zli).

Water temperature, $\mathrm{pH}$, and dissolved oxygen were also measured, and we collected large-volume plankton samples by towing a $50 \mu \mathrm{m}$ plankton net across the gueltas, horizontally and vertically, for studying zooplankton taxonomical composition.

\section{RESULTS}

Both gueltas were of freshwater (Molomhar ca $200 \mu \mathrm{S}$, Zli $190 \mu \mathrm{S}$ ), and had an alkaline $\mathrm{pH}$ (7.8-8.8). Dissolved oxygen was mostly somewhat below saturation, more so in the enclosed Molomhar (61-84 \%) than in the more open Gueltet Zli (86-102 \%). Water temperature was around $20^{\circ} \mathrm{C}$ in both gueltas, decreasing at the surface by 1-2 degrees during the night, and with little or no vertical stratification (about 0.5 degrees difference between surface and $6 \mathrm{~m}$ ).

Zooplankton in Molomhar was impoverished and composed of small individuals, all under 1 $\mathrm{mm}$. I found rare specimens of Diaphanosoma excisum Sars, 1885 copepodids of Mesocyclops sp., Thermocyclops sp., and rotifers (Brachionus sp., Keratella tropica (Apstein, 1907), Polyarthra sp., Asplanchna sp.). Cyclopoid copepods were the only taxon numerous enough for further analysis. In counting, we lumped all copepodid stages.

At Gueltet Zli, one reasonably common rotifer was Asplanchna priodonta Gosse, 1850, beside the large cladoceran Daphnia similis Claus, 1876. The only copepod seen was Metadiaptomus mau- retanicus Kiefer \& Roy, 1942, but in low numbers, too few to be analyzed.

In Molomhar, I recorded a clear 'classical' migration: the surface layers, down to $1 \mathrm{~m}$ depth, were depleted of copepods during the day. Upwardly migrating specimens during the night seemed to be recruited from the $2 \mathrm{~m}$ level (Fig. 1). Overall, numbers were low, with a maximum of about 40 animals per liter.

At Gueltet Zli, Daphnia similis showed a similar upward migration during the night, and deserted the surface during the day of 9 February. During the day, there was also a sudden increase in abundance at the 2 and $3 \mathrm{~m}$ levels (Fig. 2), from around 40 individuals per liter to about 200.

Still in Gueltet Zli, Asplanchna priodonta can perhaps best be defined as not migrating at all, although by the second day, an overall increase in numbers below $1 \mathrm{~m}$ depth occurred (Fig. 3).

\section{DISCUSSION}

It is clear that the patterns of migration between the two gueltas were different, and that these differences did not derive from any chemical of physical characteristics of the lakes involved.

In Molomhar, the zooplankton circadian rhythm was of the classical type, consistent as well with a light as with a fish predation driver. Probably, both causal factors acted in concert. This allows us to confirm the occurrence of diurnal vertical migration to an environment as extreme as the Sahara Desert.

In Gueltet Zli, Daphnia migrated normally, at least at the surface, in the first half of the cycle, but the pattern became disturbed during the last third. The reason for this was unexpected but could be observed by eye: it was the fairy shrimp Streptocephalus that moved around the guelta in one or more swarms. It avoided the Friedinger bottle and also escaped being captured by the towed plankton net. I hypothesize that the moving swarm(s) forced out the Daphnia and Asplanchna from their immediate vicinity, causing them to aggregate elsewhere, giving rise to contagious spatial distributions. Probably the fairy shrimps themselves migrated upwards during the night, as observed in laboratory conditions by Brendonck et al. (1995), adding to the disturbance. During 


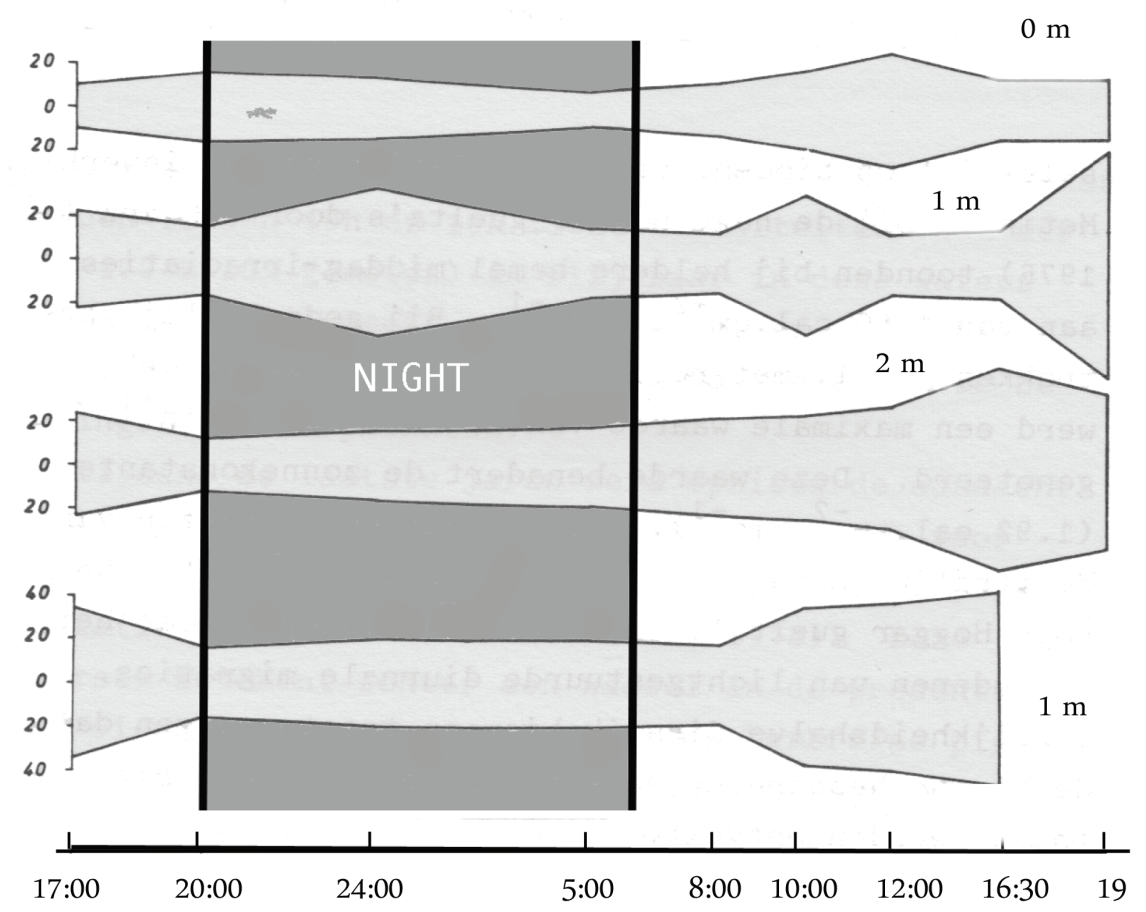

Figure 3. Diurnal migration of Asplanchna priodonta in Gueltet Zli, Adrar, Mauretania. No migration occurred at any depth level, but there was evidence of patchiness. Numbers here became extremely low during the day. Migration became insignificant below $3 \mathrm{~m}$. Migración diurna de Asplanchna priodonta en Guelta Molomhar, Adrar, Mauritania. No hubo migración a ninguna profundidad, pero hubo evidencia de parches.

the day, when they could visually be observed, the swarms never came to the surface, remained below the $1 \mathrm{~m}$ level and preferentially stayed in the shadow of the rocky shores. Voucher specimens captured with a hand net lacked carotenoid colors, known to protect from UV damage. (Hairston, 1979; Rautio \& Tartarotti, 2010). This suggests that adjusting their position to deeper or shadowed strata may have been these animals' main way to avoid excess UV radiation.

I stress that vertical migration was maintained in the absence of vertebrate predation. The main difference was that the abundance although probably not the species richness (see Gliwciz et al., 2010 , for a discussion of this phenomenon) in the plankton community increased in fishless conditions and that interference competition between the larger and smaller species occurred. The 3-4 $\mathrm{cm}$ long fairy shrimp have no protection against vertebrate predation and are mutually exclusive with fish. However, fairy shrimp have a natural tendency to form swarms, and may mechanically displace cladocerans and rotifers, causing their distribution to become patchy too and disturbing their migration pattern. This 'competition for elbow room' or avoidance of it by a different vertical incidence (Armengol \& Miracle, 2000), especially clear in rotifers, seems akin to the potential conflict between Asplanchna and Bosmina in a shallow eutrophic lake at high numerical densities, where Asplanchna migrated inversely, while Bosmina and cyclopoids migrated normally (Dumont, 1972). Exploitative competition involving Asplanchna can be ruled out, as it is a pure carnivore that, being a jelly plankter, can be physically damaged by armored crustaceans. Such conflicts may also arise intraspecifically, as shown within a Daphnia longispina population migrating vertically in a Spanish lake (King \& Miracle, 1995). Electrophoretically distinct subpopulations here displayed distinct movement types, perhaps simi- 
lar to the genetically distinct phototactic clones isolated in the laboratory by Dumont et al. (1985) and De Meester (1991).

\section{CONCLUSIONS}

To the best of my knowledge, this is the first time zooplankton vertical migration has been shown to occur in the most extreme desert of the world. Selecting two lake lets with a different predation environment revealed that as well escape from visual predators as from excess light may elicit migration. High fish predation pressure, however, impoverishes the zooplankton community to the point that very few species (in the present case only one) survive, and that cladocerans can become eliminated.

Williamson et al. (2011) provided a detailed and interesting discussion of proximate and ultimate factors involved in vertical migration, but omitted one relevant variable: interactions between the migrating animals themselves. Interand intraspecies competition for space or food indeed might be much more common than currently appreciated in shaping particular migratory patterns on a variety of time scales.

\section{ACKNOWLEDGEMENTS}

I dedicate this paper to Maria Rosa Miracle, who was deeply interested in zooplankton vertical migration as well as in the Sahara. Seven months after the field work for the present paper, Maria joined me in field work in the central Saharan Hoggar mountains, where we visited and sampled six gueltas. She told me afterwards that this was one of the high points of her life. I am happy I could offer her this experience. My thanks also go to the participants in my second Sahara expedition, who helped with the sampling for this study: the late Miel Van Cappellen, Jo Vermeir, Daniel Somers, and Ionel Miron. The late Mokhtar Ould Bontemps guided us to the gueltas, which were suggested to me by my old mentor Theodore Monod.

\section{REFERENCES}

ARMENGOL, X. \& M. R. MIRACLE. 2000. Diel vertical movements of zooplankton in lake La Cruz (Cuenca, Spain). Journal of Plankton Research, 22: 1683-1703. DOI: 10.1093/plankt/22.9.1683

BRENDONCK, L., L. DE MEESTER \& H. J. DUMONT. 1995. Evidence for sex-related differences in phototactic behaviour of Streptocephalus proboscideus (Crustacea: Anostraca). Hydrobiologia, 298: 87-91. DOI: 10.1007/BF00033803

CUSHING, D. H. 1951. The vertical migration of plankton Crustacea. Biological Reviews, 26: 159-192.

DE MEESTER, L. 1991. Evidence for intra-population genetic variability for phototactic behaviour in Daphnia magna Straus, 1820. Biologisch Jaarboek, 58: 84-93.

DODSON, S. I. 1990. Predicting diel vertical migration of zooplankton. Limnology and Oceanography, 35: 1195-1200.

DUMONT, H. J. 1972. A competition-based approach of the reverse vertical migration in zooplankton and its implications, chiefly based on a study of the interactions of the rotifer Asplanchna priodonta (Gosse) with several Crustacea Entomostraca. Internationale Revue der gesamten Hydrobiologie, 57: 1-38.

DUMONT, H. J., GUISEZ Y., CARELS, I. \& H. M. VERHEVE. 1985. Experimental isolation of positively and negatively phototactic phenotypes from a natural population of Daphnia magna Straus. A contribution to the genetics of vertical migration. Hydrobiologia, 126: 121-127. DOI: 10.1007/BF00008678

DUMONT, H. J. \& L. DE MEESTER. 1990. Are contrasting patterns of vertical migration in zooplankton the result of differential natural selection? Revista Brasileira de Biologia, 50: 867-874.

GLIWICZ, Z. M. 1986a. Predation and the evolution of vertical migration in zooplankton. Nature, 320: 746-748.

GLIWICZ, Z. M. 1986b. A lunar cycle in zooplankton. Ecology 67:883-887.

GLIWICZ, Z.M., W.A. WURSBAUGH \& E. SZYMANSKA, 2010. Absence of predation eliminates coexistence: experience from the fish-zooplankton interface. Hydrobiologia, 653: 103-117. DOI: 10.1007/s10750-010$0347-\mathrm{z}$ 
HAIRSTON, N. G. Jr. 1979. The adaptive significance of color polymorphism in two species of Diaptomus (Copepoda). Limnology and Oceanography, 24: 15-37.

HUTCHINSON, G. E. 1967. A treatise on Limnology, volume 2. Introduction to lake biology and the limnoplankton. Wiley.

KING, C. E. \& M. R. MIRACLE. 1995. Diel vertical migration by Daphnia longispina in a Spanish lake: Genetic sources of distributional variation. Limnology and Oceanography, 40: 226-231. DOI: 10.4319/1o.1995.40.2.0226.

LAMPERT W. 1989. The adaptive significance of diel vertical migration of zooplankton. Functional Ecology, 3: 21-27. DOI: $10.2307 / 2389671$

RAUTIO, M. \& B. TARTAROTTI. 2010. UV radiation and freshwater zoopl ankton: damage, protection and recovery. Freshwater Reviews, 3: 105-131. DOI: 10.1608/FRJ-3.2.157

RINGELBERG, J. 1999. The photobehaviour of Daphnia spp. as a model to explain diel vertical migration in zooplankton. Biological Reviews, 74: 397-423. DOI: 10.1111/j.1469-
185X.1999.tb00036.x

RINGELBERG, J. 2010. Diel vertical migration of zooplankton in lakes and Oceans. Springer. WILLIAMSON, C. E., O. G. OLSON, S. E. LOTT, N. D. WALKER, D. R. ENGSTROM \& B. R. HARGREAVES. 2001. Ultraviolet radiation and zooplankton community structure following deglaciation in Glacier Bay, Alaska. Ecology, 82:1748-1760. DOI: 10.1890/0012-658(2001)082[1748:URAZCS] 2.0.CO;2

WILLIAMSON, C. E., J. M. FISCHER, S. M. BOLLENS, E. P. OVERHOLT \& J. K. BRENCKENRIDGE. 2011. Toward a more comprehensive theory of zooplankton diel vertical migration: Integrating ultraviolet radiation and water transparency into the biotic paradigm. Limnology and Oceanography, 56: 1603-1623. DOI: 10.4319/1o.2011.56. 5.1603

ZARET, T. M. \& J. S. SUFFERN. 1976. Vertical migration in zooplankton as a predator avoidance mechanism. Limnology and Oceanography, 21: 804-813.

Con el apoyo de:
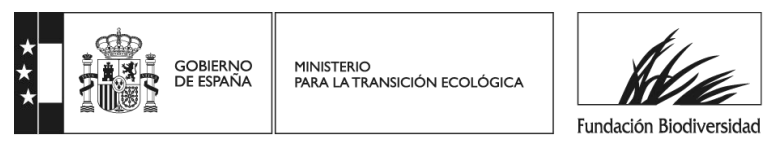